\title{
Islet Amyloid Polypeptide
}

National Cancer Institute

\section{Source}

National Cancer Institute. Islet Amyloid Polypeptide. NCI Thesaurus. Code C112881.

Islet amyloid polypeptide ( $89 \mathrm{aa}, \sim 10 \mathrm{kDa}$ ) is encoded by the human IAPP gene. This protein plays a role in the regulation of glucose metabolism. 